\title{
Pengaruh Celebrity Endorser Chelsea Olivia terhadap Citra Realfood (Studi pada Media Sosial Instagram @fitwithrealfoodid)
}

\author{
Jessica Wulandari ${ }^{1}$, H.H Daniel Tamburian ${ }^{2 *}$ \\ ${ }^{1}$ Fakultas Ilmu Komunikasi, Universitas Tarumanagara, Jakarta \\ Email: wulandarijessica15@gmail.com \\ ${ }^{2}$ Fakultas Ilmu Komunikasi, Universitas Tarumanagara, Jakarta* \\ Email:danielt@fikom.untar.ac.id
}

Masuk tanggal : 15-12-2021, revisi tanggal : 06-01-2022, diterima untuk diterbitkan tanggal : 16-01-2022

\begin{abstract}
The development of social media is used by companies to introduce products and build images. This can also be supported by the use of celebrity endorsers. One company that uses celebrity endorser services is Realfood. They use celebrity Chelsea Olivia to introduce products and build her image. This study contains the influence of celebrity endorser Chelsea Olivia on Realfood's image on social media Instagram @ fitwithrealfoodid. The purpose of this research is to find out the relationship and influence of celebrity endorsers on Realfood images. This research uses a quantitative approach with a survey method. The theory used is the celebrity endorser theory and images. In this study the researchers distributed questionnaires to 100 respondents who were Realfood's Instagram followers. The data analysis technique used is normality test, simple regression analysis test, correlation test, $t$ test and determination coefficient test. The result of the t test is 6,650>1,984, the result of the correlation test is 0.558 which means that the level of correlation is sufficient and for the results of the regression analysis test and the coefficient of determination, it shows the effect of celebrity endorser on the image of $31.1 \%$ and the rest is influenced by other variables researched.
\end{abstract}

Keywords: celebrity endorser, imagery, social media

\begin{abstract}
Abstrak
Perkembangan media sosial dimanfaatkan oleh perusahaan untuk memperkenalkan produk dan membangun citra. Hal ini juga dapat didukung oleh penggunaan celebrity endorser. Salah satu perusahaan yang menggunakan jasa celebrity endorser adalah Realfood. Ia menggunakan celebrity Chelsea Olivia untuk memperkenalkan produk dan membangun citra. Penelitian ini berisi tentang pengaruh celebrity endorser Chelsea Olivia terhadap citra Realfood pada media sosial Instagram @fitwithrealfoodid. Tujuan penelitian ini adalah untuk mencari tahu hubungan dan pengaruh celebrity endorser terhadap citra Realfood. Penelitian ini menggunakan pendekatan kuantitatif dengan metode survei. Teori yang digunakan adalah teori celebrity endorser dan citra. Pada penelitian ini peneliti menyebarkan kuesioner kepada 100 responden yang merupakan followers Instagram Realfood. Teknik analisis data yang digunakan adalah uji normalitas, uji analisis regresi sederhana, uji korelasi, uji t dan uji koefisien determinasi. Hasil dari uji t bernilai 6,650 > 1,984, hasil uji korelasi yang bernilai 0,558 yang berarti tingat korelasi yang cukup dan untuk hasil uji analisis regresi dan koefisien determinasi menunjukan adanya pengaruh celebrity endorser terhadap citra sebesar $31,1 \%$ dan sisanya dipengaruhi oleh variabel lain yang tidak diteliti.
\end{abstract}

Kata kunci: selebriti endorser, citra, media sosial 


\section{Pendahuluan}

Perkembangan komunikasi sangat pesat dari tahun ke tahun. Teknologi komunikasi itu sendiri sudah ada sejak zaman pra sejarah (3000 SM). Pada masa itu manusia mulai berkomunikasi menggunakan symbol-simbol dan isyarat. Sejak saat itu teknologi komunikasi semakin berkembang dimulai dengan memanfaatkan burung merpati, surat menyurat, telepon Hingga akhirnya pada akhir abad ke-19 mulai munculah teknologi komunikasi dengan menggunakan internet. Teknologi komunikasi ini dinamakan media sosial. Media sosial terus berkembang hingga saat ini dan semakin banyak bentuknya. Contoh dari media sosial yang digunakan oleh masyarakat, yaitu Youtube, Facebook, Whatsapp, Instagram, dan lain - lain.

Munculnya media sosial memberikan kemudahan bagi masyarakat untuk terhubung dengan teman dan saudara yang terpisah oleh jarak. Selain itu, media sosial juga memungkinkan penggunanya bukan hanya sebagai penerima informasi melainkan sebagai penyebar informasi. Tidak hanya bagi masyarakat, tetapi kehadiran media sosial juga mempermudah organisasi atau perusahaan untuk memasarkan produk yang mereka miliki.

Pemasaran melalui media sosial ini menyebabkan terjadinya proses jual beli melalui online, dimana proses transaksi juga dilakukan secara online (tidak bertemu). Pemasaran online menyebabkan terkadang pembeli kurang percaya terhadap produk dan penjual, maka perlu dibangunya citra perusahaan yang baik di mata pembeli. Citra yang baik dapat terbentuk jika kinerja perusahaan sesuai dengan apa yang diberitakan oleh perusahaan tersebut. Dengan citra yang baik maka akan membangun kepercayaan konsumen dan meningkatkan pembelian.

Media sosial yang digunakan oleh perusahaan untuk melakukan pemasaran beragam, mulai dari Facebook, Twitter, Instagram hingga Youtube. Dari semua media sosial, Instagram adalah salah satu yang paling diminati oleh perusahaan untuk melakukan pemasaran. Hal itu demikian sebab Instagram merupakan media sosial yang cepat dan mudah digunakan.

Menurut laporan dari NapoleonCat, salah satu perusahaan analisis Media Sosial Marketing asal Polandia menyebutkan bahwa pada November 2019 pengguna aktif Instagram di Indonesia sebanyak 61.610.000 akun per bulannya. Hal ini berarti hampir seperempat dari total penduduk Indonesia sudah menggunakan Instagram. Dan presentase pengguna Instagram digunakan oleh perempuan sebanyak 50,8\%, dan laki laki sebanyak $49,2 \%$.

Dalam memanfaatkan media sosial sebagai sarana pemasaran, untuk lebih membangun kepercayaan konsumen sehingga membentuk citra yang baik maka dapat dimanfaatkan juga penggunaan celebrity endorser. Saat ini sudah banyak perusahaan yang mulai menggunakan jasa celebrity endorser, salah satunya adalah Realfood.

Maka dari itu berdasarkan paparan di atas peneliti ingin mengetahui pengaruh celebrity endorser terhadap citra perusahaan. Maka dari itu peneliti memilih judul: Pengaruh Celebrity endorser Chelsea Olivia Terhadap Citra Realfood (Pada Media Sosial Instagram @ fitwithrealfoodid).

Menurut Siregar (2013, p.38), hipotesis adalah dugaan sementara yang masih belum diketahui kebenarannya. Maka dari itu hipotesis kerangka pemikiran penelitian adalah:

a. Ha: Terdapat pengaruh antara celebrity endorser Chelsea Olivia terhadap citra Realfood 
b. Ho: Tidak terdapat pengaruh antara celebrity endorser Chelsea Olivia terhadap citra Realfood

Tujuan dari penelitian ini adalah Untuk mencari tahu hubungan dan pengaruh antara celebrity endorse terhadap citra Realfood. Sehingga dua teori utama yang dipakai dalam penelitian ini, yaitu:

a. Celebrity endorser

Menurut Shimp, celebrity endorser adalah seorang figur, atau pengibur yang terkenal karena prestasinya di dalam sektor yang berbeda dari produk yang didukungnya (Dimeila, 2019). Shimp (2010) dikutip dari (Gunawan, 2015) juga mengatakan bahwa penggunaan celebrity endorser dapat diukur melalui lima indicator, yaitu:

1. Trustworthiness, yaitu mengacu pada sosok celebrity yang terpercaya dan dapat diandalkan.

2. Expertise, yaitu keahlian atau pengetahuan yang dimiliki oleh celebrity dalam merepresentasikan produk atau jasa.

3. Attractiveness, yaitu daya tarik celebrity dilihat dari fisik, kemampuan intelektual, kemampuan atletik, serta gaya hidup.

4. Respect, yaitu celebrity dikagumi dan dihormati berdasarkan kualitas dan prestasi yang dimiliki.

5. Similarity, yaitu kecocokan antara celebrity dengan audiens nya. Baik dari sisi usia, jenis kelamin, kelas sosial maupun etnik.

b. Citra

Menurut ahli bernama Soemirat dan Ardianto, citra adalah pandangan pihak lain terhadap suatu perusahaan, seseorang, suatu organisasi atau suatu kegiatan. Citra perusahaan dapat berasal dari konsumen perusahaan, pelanggan potensial, banker, pegawai perusahaan, kompetitor, distributor dan persekutuan dagang disektor perdagangan yang mempunyai pendapat tertentu terhadap perusahaan (Ridha, 2014).

Berdasarkan penjelasan dari Soleh Soemirat dan Elvinaro Ardianto dikutip dalam (Adi et al., 2015), dalam pembentukan citra terdapat 4 komponen, yaitu:

a. Kognisi

Keyakinan dalam diri seseorang terhadap dorongan. Keyakinan ini akan terbentuk jika individu diberikan informasi yang cukup dan dapat memengaruhi perkembangan kognisinya.

b. Persepsi

Hasil observasi individu terhadap sekitarnya yang berkaitan dengan proses pemaknaan. Makna yang diberikan oleh individu berdasarkan pada pengalamannya terhadap sebuah rangsangan. Kemudian kemampuan mempersespsi ini yang dapat melanjutkan proses pembentukan citra. Persepsi individu akan positif jika informasi yang diberikan dapat memenuhi kognisinya.

c. Sikap

Kecenderungan individu untuk bertindak, mempersepsikan sesuatu, memikirkan dan merasakan suatu objek, gagasan, keadaan, atau nilai. Sikap tidak sama dengan tingkah laku, tetapi sikap adalah keinginan untuk bertingkah laku dengan gaya tertentu. Sikap memiliki daya pendorong untuk menentukan apakah individu harus pro atau kontra terhadap sesuatu.

d. Motivasi

Motivasi dan sikap saling bekerja sama menggerakan respon yang diinginkan oleh rangsangan. Motif adalah dorongan dalam diri seseorang untuk melakukan suatu kegiatan demi mencapai tujuan. 


\section{Metode Penelitian}

Pendekatan yang dipakai adalah pendekatan kuantitatif. Menurut Sugiyono (2017, p.8) penelitian kuantitatif adalah penelitian yang berdasar kepada filsafat positivism, digunakan untuk meneliti populasi atau sampel tertentu, Untuk metode penelitiannya penulis menggunakan metode survei dengan pengumpulan data melalui penyebaran kuesioner. Menurut Kriyantono (2014, p.59) metode survei adalah metode yang menggunakan angket sebagai alat untuk mengumpulkan data. Tujuannya adalah untuk mendapatkan data dari sejumlah responden yang mewakili populasi. Sedangkan kuesioner adalah cara mengumpulkan data dengan cara memberi beberapa pertanyaan atau pernyataan tertulis kepada responden untuk dijawabnya (Sugiyono, 2017, p.142).

Populasi dalam penelitian ini adalah followers Instagram@fitwithrealfoodid yang berjumlah 358.000 akun per Oktober 2020. Sedangkan pengambilan sampel menggunakan rumus Slovin dan didapatkan hasil berjumlah 100 responden. Teknik pengambilan sampel menggunakan simple random sampling. Untuk uji keabsahan data digunakan uji validitas dan uji reliabilitas. Lalu untuk teknik analisis data menggunakan uji normalitas, analisis regresi sederhana, koefisien korelasi, uji t dan koefisien determinasi.

\section{Hasil Temuan dan Diskusi}

Setelah membuat operasionalisasi konsep dan menemukan butir pertanyaan maka penulis melakukan penyebaran kuesioner kepada para sampel. Setelah seluruh jawaban responden terkumpul, maka selanjutnya penulis melakukan uji keabsahan data dengan uji validitas dan uji reliabilitas serta uji lainnya, yaitu uji normalitas, uji analisis regresi sederhana, uji koefisien korelasi, uji t dan uji koefisien determinasi.

Tabel 1. Hasil Uji Validitas

\begin{tabular}{ccccc}
\hline Variabel & Soal & $\begin{array}{c}\text { Pearson } \\
\text { Correlation }\end{array}$ & Signifikasi & Keterangan \\
\hline \multirow{5}{*}{ Celebrity endorser } & P1 & 0,684 & 0.00 & Valid \\
(Model TEARS) & P2 & 0,749 & 0.00 & Valid \\
& P3 & 0,691 & 0.00 & Valid \\
& P4 & 0,682 & 0.00 & Valid \\
& P8 & 0,713 & 0.00 & Valid \\
& P9 & 0,654 & 0.00 & Valid \\
& P10 & 0,634 & 0.00 & Valid \\
& P11 & 0,833 & 0.00 & Valid \\
& P12 & 0,641 & 0.00 & Valid \\
& P13 & 0,541 & 0,00 & Valid \\
& P14 & 0,533 & 0.00 & Valid \\
& P15 & 0,576 & 0.00 & Valid \\
\hline Pitra (Komponen & P16 & 0,574 & 0.00 & Valid \\
Pembentuk Citra) & P17 & 0,553 & 0.00 & Valid \\
& P18 & 0,470 & 0.00 & Valid \\
& P19 & 0,570 & 0.00 & Valid \\
& P20 & 0,401 & 0.00 & Valid \\
& P21 & 0,573 & 0.00 & Valid \\
& & & 0.00 & Valid \\
& & & Valid \\
\hline
\end{tabular}




\section{Sumber: Hasil Pengolahan Data SPSS 22}

Berdasarkan tabel diatas maka dapat disimpulkan bahwa seluruh butir pertanyaan dinyatakan valid. Hal itu demikian sebab pearson correlation memiliki nilai diatas 0,3 dan signifikasi $\leq \alpha$, dimana nilai $\alpha$ adalah 0,05 .

Tabel 2. Hasil Uji Reliabilitas

\begin{tabular}{ccc}
\hline Variabel & Cronbach's Alpha & Keterangan \\
\hline Celebrity endorser & 0.888 & Reliabel \\
Citra & 0.661 & Reliabel \\
\hline
\end{tabular}

\section{Sumber: Hasil Pengolahan Data SPSS}

Berdasarkan tabel 4.25 (hasil uji reliabilitas) dapat disimpulkan bahwa uji reliabilitas dari variabel celebrity endorser dan citra dapat dinyatakan reliabel sebab nilai dari Cronbach's Alpha lebih dari 0,6. Dapat dilihat pada variabel celebrity endorser memiliki nilai 0.888 dan variabel citra memiliki nilai 0.661 .

Gambar 1. Hasil Uji Normalitas

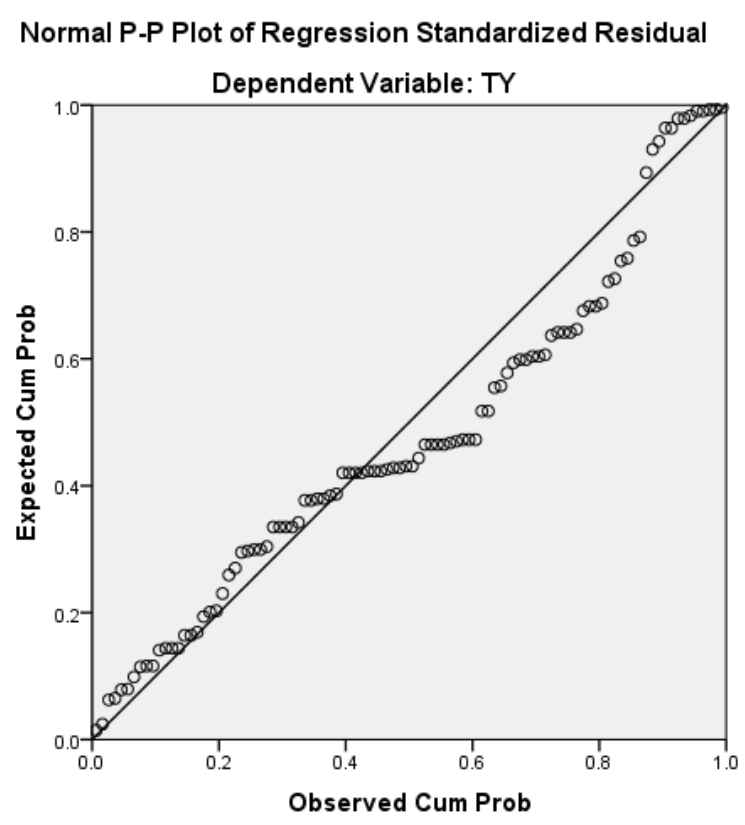

Sumber: Hasil Pengolahan Data SPSS

Setelah melakukan uji normalitas dengan uji P-P Plot, maka hasil yang didapatkan menunjukan bahwa populasi data berdistribusi normal karena garis yang menggambarkan data searah dengan garis diagonal yang ada.

Tabel 3. Hasil Uji Analisis Regresi Sederhana

\begin{tabular}{lcccc}
\hline Model & $\begin{array}{c}\text { Unstandardized } \\
\text { Coefficients }\end{array}$ & $\begin{array}{c}\text { Standardized } \\
\text { Coefficients }\end{array}$ & t & Sig. \\
\hline
\end{tabular}




\begin{tabular}{ccccccc}
\hline & \multicolumn{5}{c}{ Std. } \\
\multicolumn{1}{c}{ B } & Error & Beta & & \\
\hline 1 & (Constant) & 12.309 & 2.073 & & 5.938 & .000 \\
& Celebrity & .340 & .051 & .558 & 6.650 & .000 \\
& endorser & & & & & \\
\hline
\end{tabular}

Sumber: Hasil Pengolahan Data SPSS (2020)

$$
\begin{gathered}
\mathrm{Y}=\mathrm{a}+\mathrm{bX} \\
\mathrm{Y}=12,309+0,340 \mathrm{X}
\end{gathered}
$$
bahwa:

Berdasarkan hasil uji analisis regresi sederhana maka dapat disimpulkan

a. Koefisien konstanta bernilai positif yang berarti tanpa celebrity endorser maka citra perusahaan akan tetap baik.

b. Koefisien celebrity endorser bernilai positif berarti setiap video celebrity endorser meningkat maka citra perusahaan Realfood juga akan meningkat dan sebaliknya.

\begin{tabular}{|c|c|c|c|}
\hline \multicolumn{4}{|c|}{ Correlations } \\
\hline & & $\begin{array}{l}\text { Celebrity } \\
\text { endorser }\end{array}$ & Citra \\
\hline \multirow[t]{3}{*}{$\begin{array}{l}\text { Celebrity } \\
\text { endorser }\end{array}$} & $\begin{array}{l}\text { Pearson } \\
\text { Correlation }\end{array}$ & 1 & $.558^{* *}$ \\
\hline & Sig. (2-tailed) & & .000 \\
\hline & $\mathrm{N}$ & 100 & 100 \\
\hline \multirow[t]{3}{*}{ Citra } & $\begin{array}{l}\text { Pearson } \\
\text { Correlation }\end{array}$ & $.558^{* *}$ & 1 \\
\hline & Sig. (2-tailed) & .000 & \\
\hline & $\mathrm{N}$ & 100 & 100 \\
\hline
\end{tabular}

Tabel 4. Hasil Uji Koefisien Korelasi

Berdasarkan tabel hasil uji korelasi diketahui bahwa nilai Pearson Correlation berada di 0,558 yang menandakan variabel celebrity endorser dan citra memiliki korelasi karena berada diantara -1 dan 1 . Dan untuk tingkat kekuatan hubungan mereka, angka 0,558 berada pada tingkat cukup.

\begin{tabular}{|c|c|c|c|c|c|c|}
\hline \multirow{2}{*}{\multicolumn{2}{|c|}{ Model }} & \multicolumn{2}{|c|}{$\begin{array}{c}\text { Unstandardized } \\
\text { Coefficients }\end{array}$} & \multirow{2}{*}{$\begin{array}{c}\text { Standardized } \\
\text { Coefficients } \\
\text { Beta }\end{array}$} & \multirow[b]{2}{*}{$\mathrm{t}$} & \multirow[b]{2}{*}{ Sig. } \\
\hline & & B & $\begin{array}{l}\text { Std. } \\
\text { Error }\end{array}$ & & & \\
\hline \multirow[t]{2}{*}{1} & (Constant) & 12.309 & 2.073 & & 5.938 & .000 \\
\hline & $\begin{array}{l}\text { Celebrity } \\
\text { endorser }\end{array}$ & .340 & .051 & .558 & 6.650 & .000 \\
\hline
\end{tabular}

Tabel 5. Hasil Uji T

Sumber: Hasil Pengolahan Data SPSS

Setelah melakukan uji t diketahui nilai t hitung 6,650>1,984, maka berarti Ho ditolak dan Ha diterima, berarti ada pengaruh antara variabel celebrity endorser dan 
citra. Nilai signifikasi $0,00<0,05$ menandakan variabel celebrity endorser berpengaruh signifikan terhadap variabel citra.

Tabel 6. Hasil Uji Koefisien Determinasi

\begin{tabular}{lcccr}
\hline \multicolumn{4}{c}{ Model Summary $^{\mathbf{b}}$} \\
\hline Mode & \multicolumn{3}{c}{ Adjusted R } & Std. Error of \\
1 & $\mathrm{R}$ & R Square & Square & the Estimate \\
1 & $.558^{\mathrm{a}}$ & .311 & .304 & 3.01485 \\
\hline a. Predictors: (Constant), Celebrity endorser \\
b. Dependent Variable: Citra \\
Sumber: Hasil Pengolahan Data SPSS
\end{tabular}

Dari hasil uji koefisien determinasi diatas didapatkan nilai $R$ Square sebesar 0,311 . Hal ini berarti variabel celebrity endorser memengaruhi variabel citra sebesar $31,1 \%$

Dari hasil uji statistik maka dapat di analisis pula dengan menggunakan teori McLuhan, dimana ia menyebutkan "medium is the message". Arti dari pernyataanya tersebut adalah bahwa media lebih penting daripada isi atau konten yang disampaikan oleh media tersebut. Berdasarkan teori ini maka jawaban dari rumusan masalah adalah iya celebrity endorser memengaruhi citra perusahaan. Hal ini bukan hanya karena keahlihan, daya tarik, ataupun karaktek celebrity tersebut, melainkan karena media yang digunakan oleh celebrity tersebut. Disini ChelseaOlivia menggunakan Instagram sebagai media untuk melakukan endorser dan Instagram sendiri termasuk salah satu media sosial yang paling diminati oleh masyarakat.

\section{Simpulan}

Berdasarkan hasil penelitian dan pembahasan dalam beberapa bab sebelumnya tentang pengaruh celebrity endorser Chelsea Olivia terhadap citra Realfood, terdapat beberapa point yang ditarik menjadi kesimpulan oleh peneliti, yaitu:

a. Berdasarkan hasil penelitian, dinyatakan bahwa variabel independen (celebrity endorser Chelsea Olivia) dan variabel dependen (citra Realfood) memiliki hubungan (berkorelasi) dengan nilai korelasi 0,558. Dan tingkat kekuatan hubungan mereka berada pada tingkat cukup.

b. Selain itu, terdapat juga pengaruh antara variabel independen (celebrity endorser) terhadap variabel dependen (citra). Maka hal ini berarti celebrity endorser Chelsea Olivia memengaruhi pembentukan citra perusahaan Realfood.

c. Variabel independen (celebrity endorser Chelsea Olivia) memengaruhi variabel dependen (citra Realfood) sebesar 31,1\%. Lalu sebesar 68,9\% adalah pengaruh dari variabel lainnya yang tidak di dibahas pada penelitian ini.

Selain kesimpulan terkait dengan hasil penelitian yang telah dilakukan maka peneliti memberikan saran, yaitu:

a. Berdasarkan kesimpulan yang didapat, peneliti memberikan saran kepada Realfood untuk tetap memanfaatkan penggunaan celebrity endorser untuk membentuk citra perusahaan.

b. Untuk penelitian selanjutnya yang memiliki topik serupa disarankan untuk meneliti dengan topik yang lebih luas atau meneliti dengan variabel independen lainnya yang juga dapat berpengaruh terhadap citra perusahaan. 


\section{Ucapan Terima Kasih}

Peneliti ingin mengucapkan terima kasih kepada Fakultas Ilmu Komunikasi Universitas Tarumanagara, narasumber, serta semua pihak yang turut membantu peneliti sehingga penelitian ini dapat diselesaikan.

\section{Daftar Pustaka}

Adi, O. Y. R. P., Sudaryanto, E., \& Pratiwi, N. M. I. (2015). Kegiatan public relations oleh sales manager dalam pembentukan citra di hotel ibis budget surabaya. Jurnal Universitas 17 Agustus 1945 Surabaya. 1(02). http://jurnal.untagsby.ac.id/index.php/representamen/article/viewFile/1447/1221

Dimeila, Sabrina dan Farid (2019). Pengaruh selebriti endorser instagram terhadap minat beli followers. Jurnal Prologia Universtas Tarumanagara. 3(1). 247 254.

https://journal.untar.ac.id/index.php/prologia/article/view/6247/4351

Gunawan, F. (2015). Efektivitas penggunaan ashraf \& BCL sebagai celebrity endorser dalam iklan televisi LINE let's get rich dengan menggunakan model TEARS. Jurnal E-Komunikasi Universitas Kristen Petra. 3(2). 1-10. http://publication.petra.ac.id/index.php/ilmu-komunikasi/article/view/4928

Kompas (2019). Sebanyak Inikah Jumlah Pengguna Instagram di Indonesia?. https://tekno.kompas.com/read/2019/12/23/14020057/sebanyak-inikahjumlah-pengguna-instagram-di-indonesia

Kriyantono, R., \& Sos, S. (2014). Teknik praktis riset komunikasi. Jakarta: Prenada Media.

Ridha, W. (2014). Strategi Public Relations Dalam Membangun Citra Perusahaan Pada Excellent Islamic School (Exiss) A Ba Ta Srengseng Jakarta Barat. Skripsi. Universitas Islam Negeri Syarif Hidayatullah. Jakarta. http://repository.uinjkt.ac.id/dspace/handle/123456789/26758

Siregar, S. (2013). Metode penelitian kuantitatif. Jakarta: Kencana

Sugiyono. (2017). Metode penelitian kuantitatif, kualitatif dan R\&D. Bandung: Alfabeta 